\title{
IMPLEMENTASI STRATEGI ACTIVE LEARIING DALAM PEMBELAJARAN FIQH SISWA MADRASAH TSANAWIYAH MUHAMMADIYAH GEDONTENGEN KOTA YOGYAKARTA
}

\author{
Sutinah \\ Sekolah Tinggi Agama Islam Masjid Syuhada Yogyakarta \\ E-mail: staimsyogyakarta@yahoo.co.id \\ Nahrasyiah Kumala \\ Sekolah Tinggi Agama Islam Masjid Syuhada Yogyakarta \\ E-mail: nahrasyiah136@gmail.com
}

\section{Abstrak}

Penelitian ini bertujuan untuk mengetahui (1) penerapan strategi active learning dalam pembelajran Fiqih di MTs Muhammadiyah Gedongtengen Kota Yogyakarta (2) hasil penerapan strategi active learning di MTs Muhammadiyah Gedongtengen Kota Yogyakarta. Jenis penelitian ini adalah penelitian kualitatif. Penelitian ini merupakan penelitian populasi karena subjek penelitian ini hanya 29 siswa yang terdiri dari kelas VII A, dan kelas VII B. Sedangkan metode untuk pengumpulan data menggunakan metode angket, wawancara, observasi dan dokumentasi. Analisis data yang digunakan dalam penelitian ini adalah analisis kualitatif deskriptif. Hasil penelitian menunjukkan: (1) penerapan strategi active learning dalam pembelajaran Fiqih di MTs Muhammadiyah Gedongtengen Kota Yogyakarta meliputi tujuan, manfaat, hal-hal yang dilakukan guru agar siswa selalu merasa nyaman dan senang ketika proses belajar mengajar, ha-hal yang dilakukan guru dalam memberikan motivasi agar anak didik ikut berperan aktif dalam proses pembelajaran ketika mengajar. (2) hasil penerapan strategi active learning dalam pembelajaran Fiqih belum 100\% berhasil. Hal tersebut ditunjukkan dengan hasil angket yang diperoleh dari siswa serta observasi disekolah.

Kata Kunci: Implementasi, Active Learning, Fiqh

\section{Abstract}

The aim of this study was to find out (1) how the application of active learning strategy in Fiqh subject at MTs Muhammadiyah 
Kota Yogyakarta (2) how the results of active learning strategy at MTs Muhammadiyah Kota Yogyakarta.The approach of this study was qualitative and population study. Twenty nine students was enrolled to this study consist of of VII A and VII B class. This study used a questionnaire, interview, observation and dentation methods. Data were analyzed with descriptive qualitative analysis. The results showed that: (1) application of active learning strategy in Fiqh subject at MTs Muhammadiyah Kota Yogyakarta includes goals, benefits, things that teachers did toward their students to be comfortable and pleased when the process of teaching and learning, and strategy that teachers can do while giving motivation toward their students to get involved in learning process. (2) application of active learning strategy in Figh subject was not 100\% succeed. This can be shown by the results of questionnaires that have been obtained from students and observation in school.

Keywords: Implementation, Active Learning, Fiqh

\section{PENDAHULUAN}

\section{A. Latar Belakang Masalah}

Pendidikan merupakan salah satu kebutuhan bagi setiap orang, sedangkan dalam ajaran Agama Islam menuntut ilmu merupakan salah satu kewajiban yang harus dilaksanakan sejak dari lahir sampai akhir hayat. Pendidikan tersebut tentunya menyeluruh, bukan hanya pendidikan umum, tetapi juga pendidikan Agama seperti: Aqidah, Akhlak, maupun Fiqih.

Fiqih merupakan salah satu sub pokok bahasan mata pelajaran pendidikan agama Islam yang diarahkan untuk mengetahui, memahami, menghayati dan mengamalkan hukum Islam yang menjadi dasar pandangan hidup melalui kegiatan, pengajaran, pelatihan dan pembiasaan.

Madrasah Tsanawiyah Muhammadiyah Gedongtengen kota Kota Yogyakarta salah satu lembaga pendidikan yang setara dengan SMP yang berada di tengah-tengah kota Kota 
Yogyakarta. Madrasah Tsanawiyah Muhammadiyah Gedongtengen kota Kota Yogyakarta mengajarkan pelajaran fiqih pada setiap jenjang mulai dari kelas tujuh hingga kelas sembilan.

Alhamdulillah bulan Oktober 2017, peneliti mendapat kesempatan studi banding ke Malaysia yaitu ke Internasional Islamic School Malaysia (IISM) untuk mengamati proses pembelajaran dan kurikulum yang digunakan, peneliti waktu itu sempat masuk kelas yang mata pelajarannya bahasa Inggris, dan kelas yang mengajar tahsin, disitu peneliti melihat sekolah tersebut menggunakan Active Learning dalam penyampaian pelajaran bahasa Inggris dan tahsin.

Berdasarkan pengalaman studi banding itulah, maka peneliti tertarik untuk meneliti tentang pembelajaran mata pelajaran fiqih dengan menggunakan strategi Active Learning di Madrasah Tsanawiyah Muhammadiyah Gedongtengen Kota Yogyakarta. Ketika peneliti mengobservasi di Madrasah Tsanawiyah Muhammadiyah Gedongtengen sudah menggunakan active Learning dalam mengajarkan mata pelajaran Fiqih. Oleh karena itu, peneliti mencoba untuk meneliti seberapa besar hasil yang dapat diterima oleh siswa tentang pelajaran fiqih.

Berbicara pendidikan Agama Islam tentu tidak bisa dipisahkan dengan fiqih, karena fiqih selalu berhubungan dengan manusia. Proses belajar mengajar merupakan upaya pemberian ilmu pengetahuan atau transfer of knowledge dari satu generasi ke generasi berikutnya. Sementara proses belajar mengajar ditinjau dari ruang lingkup terdiri dari beberapa komponen dan unsur. Komponen tersebut adalah 
tujuan, bahan pelajaran, kegiatan belajar mengajar, metode, alat dan evaluasi. ${ }^{1}$

Mengajar tidak hanya menyampaikan materi dari guru kepada siswa, tetapi mengajar juga membutuhkan keaktifan atau keterlibatan mental dan tindakan pelajar itu sendiri. Artinya setelah kegiatan belajar mengajar, ada hasil dan efeknya, hal ini dapat tercapai bila menggunakan strategi belajar yang aktif. Dengan belajar yang aktif siswa dapat memecahkan masalah, menemukan contoh-contoh keterampilan, melakukan tugas dengan kemamapuan yang mereka miliki yang harus mereka capai. ${ }^{2}$

Belajar aktif melibatkan mental, fisik, dan juga tindakan, cara belajar siswa yang tidak sama, ada yang senang membaca/melihat, mendengar/diskusi dan ada juga yang senang praktik lansung. Oleh karena itu, untuk membantu siswa secara maksimal dalam belajar, maka kenyamanan dan kesenangan dalam belajar sedapat mungkin diperhatikan.

Guru dituntut harus bervariasi dalam menggunakan strategi mengajar, guna membantu kecenderungan siswa dalam hal cara belajar. Penjelasan dan pemeragaan dalam penyampaian informasi belum tentu membuahkan hasil yang maksimal. Karena hasil belajar hanya akan diingat dan dirasakan manfaatnya oleh siswa apabila ikut terlibat, maka pembelajaran Active learning mutlak diperlukan. ${ }^{3}$

1 Syaiful Bahri Djamarah, Aswa Zein, Strategi Belajar Mengajar, (Jakarta : Rineka Cipta, 2002), hlm. 41.

2 Mei Silberman, Active Learning 101 Pembelajaran Aktif, (Kota Yogyakarta : Pustaka Insan Madani, 1996), hlm. xiii

3 Umi Machmudah, Abdul Wahab Rosyidi, Active Learning Dalam Pembelajaran Bahasa Arab,(Malang : UIN- Malang Press, 2008), hlm. iii-iv. 
Active learning mencoba membuktikan bahwa semua anak mempunyai potensi untuk berkembang sesuai dengan fase-fasenya. Dengan strategi ini potensi siswa dapat terus berkembang dengan melihat kreatifitasnya dalam memecahkan masalahnya. Active learning menjadikan siswa sebagai subjek belajar dan berpotensi untuk meningkatkan kreatifitas dalam setiap pelajaran yang diberikan, baik di dalam maupun di luar kelas dalam hal ini siswa diarahkan untuk belajar aktif dengan cara menyentuh (touching), merasakan (feeling) dan melihat (looking) lansung serta mengalami sendiri, sehingga pembelajaran lebih bermakna dan mudah dipahami siswa.

Belajar fiqih merupakan usaha yang tidak gampang dan kadang menjenuhkan, karena salah satu bidang ilmu dalam syariat Islam yang secara khusus membahas persoalan hukum yang mengatur berbagai aspek kehidupan manusia, baik kehidupan pribadi, bermasyarakat maupun kehidupan manusia dengan Tuhannya. Fikih juga sebagai pengetahuan seorang muslim tentang kewajiban dan haknya sebagai hamba Allah, fiqih juga membahas tentang cara beribadah, rukun Islam dan juga hubungan antar manusia sesuai dengan dalil-dalil yang terdapat dalam al-qur'an dan Sunnah. ${ }^{4}$

Dalam bahasa Arab, secara harfiah fiqih berarti pemahaman yang mendalam terhadap suatu hal. Beberapa ulama memberikan uraian bahwa arti fiqih secara terminologi yaitu: fikih merupakan suatu ilmu yang mendalami hukum Islam yang diperoleh melalui dalil-dalil al-

${ }^{4}$ Zainal Aqib, Profesionalisme Guru Dalam Pembelajaran, (Surabaya : Insan Cendikia, 2010), hlm. 82. 
qur'an dan Sunnah. Selain itu fiqih merupakan ilmu yang juga membahas hukum Islam (syariah) dan hubungannya dengan kehidupan manusia sehari-hari, baik dalam ibadah maupun dalam muamalah. ${ }^{5}$

Berdasarkan latar belakang di atas maka peneliti tertarik untuk meneliti pada lembaga pendidikan tersebut. Adapun fokus penelian ini adalah bagaimana proses pembelajaran dengan menggunakan strategi active learning di Madrasah Tsanawiyah Muhammadiyah Gedongtengen, benarkah Active Learning dapat menghasilkan out put yang berkualitas. Berdasarkan uraian di atas maka peneliti tertarik untuk mengadakan penelitian dengan judul Implementasi Strategi Active learning Dalam Pembelajaran fiqih Siswa Kelas VII di Madrasah Tsanawiyah Muhammadiyah Gedongtengen Kota Yogyakarta Tahun Pelajaran 2017/2018.

\section{B. Rumusan Masalah}

Berdasarkan latar belakang di atas, maka dapatlah dirumuskan masalah: Pertama, bagaimana penerapan Strategi Active Learning dalam pembelajaran fiqih siswa kelas VII di Madrasah Tsanawiyah Muhammadiyah Gedongtengen Kota Yogyakarta? Kedua, bagaimana hasil penerapan strategi Active learning dalam pembelajaran fiqih di Madrasah Tsanawiyah Muhammadiyah Gedongtengen Kota Yogyakarta?

\section{Batasan Masalah}

Untuk lebih fokus, masalah dalam penelitian ini dibatasi pada: Pertama, strategi Active learning pada pembelajaran fiqih siswa Madrasah Tsanawiyah Muhammadiyah Gedongtengen Kota Yogyakarta. Kedua, hasil hlm. 6-7.

${ }^{5}$ Amir Syaifudin, Garis-Garis Besar Fiqih, (Bogor : Kencana, 2003), 
penerapan strategi Active Learning dalam pembelajaran fiqih, hal tersebut didapat dari hasil angket, wawancara dan observasi.

\section{Signifikansi Penelitian}

Signifikansi penelitian ini adalah: Pertama, secara teoritis, penelitian ini diharapkan dapat menjadi salah satu kontribusi terhadap pembelajaran fiqih dengan menggunakan Active Learning di Madrasah Tsanawiyah Muhammadiyah Gedongtengen Kota Yogyakarta. Kedua, cecara praktis, penelitian ini diharapkan sebagai langkah awal untuk kemudian memunculkan Active Learning terhadap pelaksanaan pelajaran Pendidikan Agama Islam tidak hanya pelajaran fiqih.

\section{LANDASAN TEORI}

\section{A. Kajian Riset Sebelumnya}

Penelitian tentang strategi active learning pernah dilakukan oleh mahasiswa SEKOLAH TINGGI AGAMA ISLAMMS di Madrasah Tsanawiyah Muhammadiyah Karangkajen pada tahun 2010 yang melakukan telaah tentang Strategi Active learning pada mata pelajaran bahasa Arab. Peneliti hanya fokus pada motivasi siswa terhadap pelajaran bahasa arab dengan menggunakan strategi active learning. Penelitian tersebut menghasilkan siswa senang atau tertarik belajar bahasa Arab dengan menggunakan strategi active learning.

\section{B. Kerangka Teori}

\section{Pengertian Active Learning}

Active Learning adalah salah satu cara untuk mengikat informasi yang baru kemudian menyimpannya ke dalam 
otak. ${ }^{6}$ Pembelajaran Active Learning merupakan sebuah kesatuan sumber kumpulan strategi-strategi pembelajaran yang komprehensif. Pembelajaran aktif meliputi berbagai cara untuk membuat peserta didik aktif sejak awal melalui aktivitas-aktivitas yang membangun kerja kelompok dan dalam waktu singkat peserta didik berpikir tentang materi pelajaran. Perlunya belajar aktif adalah untuk membantu siswa mempelajari sesuatu yang sebaik-baiknya. Karena belajar aktif akan membantu untuk mendengarkan, melihat, mengajukan pertanyaan tentang pelajaran tertentu dan mendiskusikannya dengan lain ${ }^{7}$.

Peserta didik diharapkan dapat melakukan, memecahkan masalah sendiri, menemukan contoh-contoh, mencoba keterampilan-keterampilan dan tugas-tugas pada pengetahuan yang telah siswa miliki ataupun yang harus dicapai, karena semakin banyak siswa terlibat dalam belajar, maka siswa semakin banyak mengerti dan mengingat pembelajaran dalam waktu yang lebih lama karena kuncinya belajar adalah keterlibatan.

Pembelajaran Active learning dimaksudkan untuk mengoptimalkan penggunaan semua potensi yang dimiliki anak didik, sehingga semua anak didik dapat mencapai hasil belajar yang maksimal sesuai dengan karakteristik pribadi yang mereka miliki. Selain itu pembelajaran Active learning juga dimaksudkan untuk menjaga perhatian anak didik agar tetap tertuju pada proses pembelajaran .8

6 Hisyam Zaini, Barmawi Munthe, Sekar Ayu Aryani, Strategi Pembelajaran Aktif, (Yoyakarta : Pustaka Insan Madani, 2008), hlm. xiv. hlm. xxi.

7 Mei Silberman, Active Learning 101 Strategi.............................,

8 Umi Machmudah, Abdul Wahab Rosyidi, Active Learning , hlm. 63. 
Menurut Bonwell yang dikutip Umi Machmudah, Abdul Wahab Rosyidi, pembelajaran active learning memiliki karakteristik sebagai berikut: Pertama, penekanan proses pembelajaran bukan pada penyampaian informasi oleh pengajar, melainkan pada pengembangan keterampilan analitis dan kritis terhadap topik atau permasalahan yang dibahas. Kedua, siswa tidak hanya mendengarkan pelajaran secara pasif, tetapi mengerjakan sesuatu berkaitan dengan materi pembelajaran. Ketiga, penekanan pada eksplorasi nilainilai dan sikap-sikap berkenaan dengan materi pelajaran. Keempat, siswa lebih dituntut berpikir kritis, menganalisis dan melakukan evaluasi. Kelima, umpan balik yang lebih cepat akan terjadi pada proses pembelajaran. ${ }^{9}$

Penggunaan strategi active learning selalu penyampaian materi pelajaran yang baru harus dikaitkan dengan berbagai pengetahuan dan pengalaman yang ada sebelumnya, agar siswa dapat belajar secara aktif guru perlu menciptakan strategi yang tepat, sehingga peserta didik mempunyai motivasi yang tinggi untuk belajar. 10 Mc. Keachi mengemukakan seperti yang dikutip Dimyati, Mudjiono, ada beberapa dimensi pembelajaran Active learning yaitu: Pertama, partisipasi siswa dalam menetapkan tujuan kegiatan belajar mengajar. Kedua, penekanan pada aspek afektif dalam belajar. Ketiga, partisipasi siswa dalam kegiatan pembelajaran, terutama yang berbentuk intraksi antar siswa. Keempat, penerimaan guru terhadap perbuatan dan sumbangan siswa yang kurang relevan atau salah. Kelima,

9 Umi Machmudah, Abdul Wahab Rosyidi, Active Learning hlm. 64

10 Umi Machmudah, Abdul Wahab Rosyidi, Active Learning , hlm. 70 
kelompok kelas sebagai kelompok. Keenam, kesempatan yang diberikan kepada siswa untuk mengambil keputusan yang penting dalam kegiatan sekolah. Ketujuh, jumlah waktu yang digunakan untuk menangani masalah pribadi siswa baik yang berhubungan ataupun yang tidak berhubungan dengan sekolah. ${ }^{11}$

Penelitian menunjukkan bahwa semakin banyak siswa terlibat dalam belajar, maka siswa lebih banyak mengerti dan mengingat pembelajaran dalam waktu yang lebih lama, kuncinya adalah keterlibatan. Howard Hendricks dalam bukunya "Teaching to changes Lives" mengatakan pembelajaran maksimal adalah hasil dari keterlibatan maksimal." Survei menunjukkan bahwa seseorang kehilangan pekerjaannya bukan karena pengetahuannya, akan tetapi karena ketidakmampuannya dalam bekerja sama. Tom Jackson dalam bukunya "Activities that Teach" Penguasaan Life skill merupakan persyaratan dasar untuk semua. ${ }^{12}$

\section{Prinsip-prinsip Active Learning}

Dalam kegiatan belajar mengajar prinsip merupakan hal yang penting, sehingga dengan prinsip tersebut kegiatan belajar mengajar dapat dilakukan secara optimal. Menurut Sriyono, dkk ada beberapa prinsip belajar yang dapat menunjang tumbuhnya belajar aktif yakni: 13

a. Stimulus Belajar. Stimulus belajar merupakan suatu bentuk penyampaian informasi. Dengan stimulus peserta

11 Dimyati, Mudjiono, Belajar dan Pembelajaran, (Jakarta: PT. Rineka Cipta, 2006), hlm. 119.

12 Umi Machmudah, Abdul Wahab Rosyidi, Active Learning hlm. 71 .

13 Sriyono,dkk, Teknik Belajar Dalam CBSA, ( Jakarta : PT. Rineka Cipta, 1992), hlm. 15-17. 
didik diharapkan dapat merespon materi pelajaran dengan baik.

b. Perhatian dan Motivasi. Perhatian dan motivasi merupakan prasyarat utama dalam proses belajar mengajar. Tanpa ada perhatian dan motivasi niscaya hasil belajar yang dicapai oleh peserta didik tidak akan optimal. Perhatian dan motivasi belajar dapat diberikan secara bervariasi, seperti adanya pengulangan informasi, memberikan pertanyaan-pertanyaan, menggunakan alat bantu belajar lainnya yang dapat memberikan perhatian terhadap peserta didik. Motivasi belajar dapat tumbuh dari dua hal: Pertama, dari peserta didik itu sendiri yaitu berupa kebutuhan akan belajar. Kedua, dari pendidik, misalnya dengan memberi penghargaan terhadap prestasi peserta didik.

c. Respon yang dipelajari. Konsekuensi logis dari pembelajaran aktif adalah keterlibatan subjek didik secara penuh. Untuk itu semua respon yang dapat dipelajari oleh subjek didik harus mampu menunjang tujuan instruksional sehingga dapat mengubah prilakunya kearah yang lebih baik. Respon ini dapat ditempuh melalui respon fisik (motorik) dan intelektual. Hal ini dikarenakan karakteristik atau prilaku tidak hanya dipengaruhi oleh faktor keturunan (hereditas) namun juga dipengaruhi oleh lingkungan.

d. Penguatan. Setiap tingkah laku yang diikuti oleh kepuasaan terhadap kebutuhan peserta didik akan mempunyai kecenderungan untuk diulang kembali ketika diperlukan. Sumber penguat belajar untuk menemukan kebutuhan berasal dari luar dapat berupa nilai, 
pengakuan prestasi, ganjaran dan sebagainya, sedangkan penguat dari dalam dirinya terjadi apabila respons yang dilakukan oleh peserta didik dirasa memuaskan dirinya dan sesuai dengan kebutuhannya.

e. Pemakaian dan pemindahan (Asosiasi). Belajar dengan memperluas pembentukan asosiasi dapat meningkatkan kemampuan subjek didik untuk memindahkan apa yang sudah dipelajari kepada situasi lain yang berupa masa mendatang. Asosiasi ini dapat dibentuk melalui pemberian bahan yang bermakna, berorientasi pada pengetahuan yang dimiliki peserta didik, pemberian latihan yang teratur, pemberian contoh yang jelas dan pemecahan masalah yang serupa dilakukan dalam situasi yang menyenangkan.

\section{Indikator Active Learning}

Menurut Nana Sudjana, sebagaimana yang di kutip oleh Ahmad Rohadi dan Abu Ahmadi, ada beberapa indikator mengenai belajar aktif, yaitu: ${ }^{14}$

a. Dari peserta didik yaitu: Pertama, keinginan, keberanian menampilkan minat, kebutuhan dari permasalahannya. Kedua, keinginan dan keberanian serta kesempatan untuk berpartisipasi dalam persiapan, proses dan kelanjutan belajar. Ketiga, menampilkan berbagai usaha/kreativitas belajar dalam menjalani dan menyelesaikan kegiatan belajar mengajar hingga mencapai keberhasilan. Keempat, kebebasan/ keleluasaan melakukan hal tersebut di atas tanpa tekanan guru/pihak lainnya.

${ }^{14}$ Ahmad Rohani, Abu Ahmadi, Pengelolaan Pengajaran, (Jakarta : PT. Rineke Cipta, 1995 ), hlm. 59-60. 
b. Dari guru, yaitu: Pertama, usaha mendorong, membina gairah dan partipasi peserta didik secara aktif. Kedua, peranan guru tidak mendominasi kegiatan proses belajar peserta didik. Ketiga, memberi kesempatan peserta didik untuk belajar menurut cara dan keadaan masing-masing. Keempat, menggunakan berbagai jenis metode mengajar dan pendekatan multi media.

c. Dari segi program, yaitu: Pertama, tujuan pengajaran dan konsep maupun isi pelajaran hendaknya sesuai dengan kebutuhan minat dan kemampuan subjek didik. Kedua, program cukup jelas, dapat dimengerti dan menantang peserta didik untuk melakukan kegiatan belajar. Ketiga, bahan pengajaran mengandung fakta/informasi, konsep, prinsip dan keterampilan.

d. Dari segi situasi belajar, yaitu: Pertama, ada iklim hubungan erat antara guru dengan peserta didik, guru dengan guru dan antar unsur pimpinan sekolah. Kedua, ada gairah dan kegembiraan peserta didik, sehingga mereka memiliki motivasi kuat dan kesempatan mengembangkan cara belajar masing-masing.

e. Dari segi Sarana Belajar, yaitu: Pertama, ada sumbersumber belajar bagi peserta didik. Kedua, fleksibilitas waktu untuk kegiatan belajar. Ketiga, dukungan dari berbagai jenis media pelajaran. Keempat, kegiatan belajar peserta didik tidak terbatas dalam kelas tapi juga diluar kelas. 


\section{Manfaat Active Learning}

Active learning memiliki manfaat yang besar dalam rangka pengembangan pendidikan disekolah dan ini dapat dilihat dari beberapa tinjauan: 15

a. Ditinjau dari tujuan dan hakikat pendidikan secara umum, pendidikan itu merupakan upaya untuk mengantarkan siswa kepada kedewasaan dalam arti perkembangan yang optimal, yakni agar anak didik mampu mengembangkan potensi yang ada.

b. Peran serta siswa dalam berbagai kegiatan belajar secara aktif dapat meningkatkan keterlibatan mental siswa dalam proses belajar-mengajar

c. Kegiatan belajar mengajar dapat memberikan keleluasaan kepada siswa untuk berkomunikasi dua arah, sehingga dapat memberikan peluang bagi guru untuk menilai keberhasilan pengajaran yang dilaksanakannya.

d. Active learning merupakan usaha untuk meningkatkan kemampuan siswa dan guru.

\section{Kelebihan dan Kekurangan Active learning}

a. Kelebihan Active learning

Menurut Tayar Yusuf Active learning memiliki kelebihan sebagai berikut: Pertama, active learning dapat menumbuhkan suasana kelas yang dinamis dan hidup, dimana masing guru dan anak didik sama-sama aktif. Kedua, adanya komunikasi dua arah timbal balik guru dan anak didik, mendorong suasana yang responsif dan bergairah dari anak didik. Ketiga, anak didik merasa terlibat langsung secara intelektual dan emosional dalm

15 Cece Wijaya, Djadja Djadjur, A. Tabroni Rosyan, Upaya Pembaharuan Dalam Pendidikan dan Pengajaran, (Bandung: Remaja Rosdakarya, 1992), hlm. 182-183. 
proses pengajaran sehingga memungkinkan kemampuan anak didik berkembang secara optimal. Keempat, mendorong guru untuk menyiapkan dan menyajikan pelajaran secara optimal dengan meningkatkan kemampuan menguasai materi atau bahan pelajaran, kemampuan dalam menguasai metode-metode dan menerapkannya dalam situasi belajar mengajar yang sesuai dengan media pembelajaran. Kelima, dengan adanya sumber belajar/lingkungan belajar yang diciptakan secara optimal oleh guru dapat merangsang anak didik untuk aktif dan kreatif dalam mengembangkan kemampuan dan penalarannya. Keenam, siswa memperoleh kepuasan intelektual dan emosional dalam belajar. Karena minat dan kemampuan dapat tersalurkan, sehingga timbul kepercayaan diri pada anak didik, optimisme dan semangat belajar yang menyenangkan. ${ }^{16}$

b. Kekurangan Active Learning

Selain memiliki banyak kelebihan Active Learning juga mempunyai kekurangan yaitu: Pertama, pengajaran dengan Active Learning memerlukan kesiapan yang matang dari pihak guru berupa rencana pengajaran yang akan disampaikan kepada anak didik. Hal ini tentu menjadi kendala bagi seorang guru yang memiliki mental pemalas dan disiplin rendah. Akibatnya pengajaran kehilangan arti dan tujuan. Kedua, disatu sisi memberikan kebebasan dan demokratisasi belajar kepada anak didik dan mampu mendorong terciptanya kondisi belajar mengajar yang aktif dan kondusif. Namun disisi

16 Tayar Yusuf, Syaiful Anwar, Metodologi Pengajaran Agama dan Bahasa Arab, (Jakarta: Raja Grafindo Persada, 1995), hlm. 148. 
lain terlalu memberikan kebebasan dan demokratisasi bagi anak didik dapat berakibat anarkhis yang menjadi bumerang dalam pembelajaran. ${ }^{17}$

\section{Strategi Active Learning}

Menurut Melvin dalam bukunya berjudul Active Learning 101 Strategi pembelajaran Aktif terdapat 101 strategi untuk mengaktifkan kegiatan belajar siswa. Namun dalam penelitian ini hanya beberapa saja yang peneliti paparkan, yaitu quiz team, readingaloud, active debate dan vidio critic. Adapun alasan mengapa strategi ini dipilih karena sering terjadi guru mengajar namun siswa tidak belajar. Dengan strategi ini diharapkan disamping guru mengajar, siswa juga belajar. Jadi antara guru dan siswa sama-sama aktif. Dengan adanya keaktifan dari guru dan siswa diharap potensi yang ada dalam diri peserta didik dapat teraktualisasikan sehingga dapat meningkatkan kualitas pembelajaran dan tujuan pembelajaran dapat tercapai. 18

a. Quiz Team/ Menguji Tim

Kegiatan ini merupakan teknik untuk meningkatkan kemampuan tanggung jawab peserta didik terhadap apa yang dipelajari melalui cara yang menyenangkan dan tidak menakutkan.

b. Reading Aloud / Membaca Keras

Kegiatan ini merupakan sebuah teknik hebat untuk merangsang diskusi dan mendapatkan pemahaman lebih mendalam tentang berbagai isu kompleks. Format tersebut

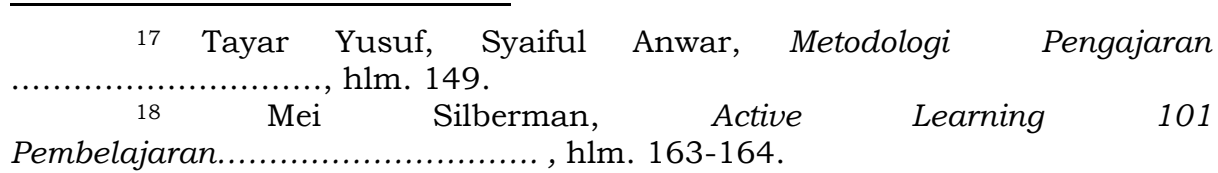


mirip dengan sebuah perdebatan namun kurang formal dan berjalan dengan lebih cepat.

c. Active Debate/ Perdebatan Aktif

Suatu perdebatan dapat menjadi sebuah metode berharga untuk mengembangkan pemikiran dan refleksi, khususnya jika para peserta didik diharapkan mengambil posisi yang bertentangan dengan pendapatnya. Ini adalah sebuah strategi untuk suatu perbuatan yang secara aktif melibatkan setiap peserta didik dalam kelas, bukan hanya orang-orang yang terlibat.

d. Video Critic/Membahas Program Video

Sering kali melihat video-video pendidikan merupakan persoalan pasif. Para peserta didik duduk di tempat duduknya dengan menunggu untuk dihibur, ini adalah suatu cara aktif untuk membuat para peserta didik menyaksikan suatu video. Video critic ini peserta didik tidak hanya menonton tayangan video saja. Akan tetapi peserta didik juga diminta untuk mengkritisi atas apa yang baru saja ditayangkan jadi dalam video critic ini peserta didik benar-benar di tuntut untuk memperhatikan tayangan video secara seksama. ${ }^{19}$

\section{Pembelajaran Fiqih}

\section{Pengertian Belajar}

Belajar adalah suatu proses dasar dari perkembangan hidup manusia melakukan perubahan-perubahan kuantitatif individu sehingga tingkahlakunya berkembang. 20 Dakir mengemukakan bahwa definisi belajar secara umum, ciri-

\footnotetext{
19 Mei Silberman,

Pembelajaran........................., hlm. 124.
20 Wasty Soemanto, Psikologi Pendidikan,(Jakarta: Rineka Cipta, 1990), hlm. 99.
} 
cirinya adalah perbuatan-perbuatan yang menuju sesuatu yang lebih maju lagi dan perbuatan-perbuatan tersebut atas dasar latihan yang disengaja. 21 Sumadi Suryabrata menyimpulkan definisi tentang belajar sebagai berikut: Pertama, belajar itu membawa perubahan (Actual atau potensial). Kedua, perubahan itu pada pokoknya adalah didapatkannya kecakapan baru. Ketiga, perubahan itu terjadi karena usaha. ${ }^{22}$ Berdasarkan pendapat di atas dapat penulis simpulkan bahwa belajar merupakan suatu proses kegiatan yang menimbulkan perubahan pada diri seseorang yang belajar.

\section{Pengertian Fiqih}

Fiqih adalah salah satu bidang ilmu dalam syariat Islam yang secara khusus membahas persoalan hukum, yang mengatur sebagai aspek kehidupan manusia, baik kehidupan peribadi maupun kehidupan bermasyarakat dan kehidupan dengan Tuhan. Fiqih membahas tentang cara bagaimana cara tentang beribadah, tentang perinsip Rukun Islam dan hubungan antar manusia sesuai dengan dalil-dalil yang terdapat dalam al-Quran dan Sunnah. ${ }^{23}$

\section{Muatan Fiqih}

Berdasarkan hubungan antar sesama manusia, maka fiqih dapat dibagi menjadi beberapa cabang, diantaranya:

a. Hubungan antar sesama manusia berkaitan dengan harta dan kebutuhannya kepada pemilikan harta itu. Aturan

21 Dakir, Psikologi, (Kota Yogyakarta: Pustaka Pelajar, 1991), hlm. 1989), hlm. 249.

22 Sumadi Suryabrata, Psikologi Pendidikan, (Jakarta: Rajawali Press,

23 Sumadi Suryabrata, Psikologi Pendidikan..........., hlm. 7. 
dalam bentuk ini disebut dengan fiqih muamalat, seperti didalamnya: juai beli, sewa menyewa dan serikat usaha.

b. Hubungan antar sesama manusia berkaitan dengan penyaluran nafsu syahwat dalam mendapatkan keturunan yang sah aturan dalam bentuk ini disebut dengan fikih munakahat, seperti pernikahan, perceraian dan kekerabatan.

c. Hubungan antar sesama manusia berhubungan dengan kepemilikan harta yang timbul sebagai akibat sesuatu kematian dikalangan keluarga. Aturan dalam bentuk ini disebut dengan fiqih mawaris atau kewarisan

d. Hubungan antar sesama manusia terkait dengan terjadinya kejahatan dan sanksi untuk mencegahnya. Aturan dalam bentuk ini disebut dengan fiqih jinayat atau pidana

e. Hubungan antar sesama manusia berkaitan dengan usaha mendapatkan hak dan keadilan dipengadilan. Aturan dalam bentuk ini disebut dengan fiqih murafaat atau qada disebut dengan hukum acara.

f. Hubungan antar manusia dan antar manusia sebagai kelompok dengan pemimpinnya dalam kehidupan bernegara dan berbangsa. Aturan dalam bentuk ini disebut dengan fiqih Dusturiyah atau hukum tata negara.

g. Hubungan antar sesama manusia dalam suatu negara dengan negara lain dalam masa perang dan damai. Aturan dalam bentuk ini disebut dengan fiqih dualiyah. ${ }^{24}$

\section{Pembelajaran Fiqih sebagai Pendidikan Nilai}

Pembelajaran mata pelajaran fiqih pada hakikatnya merupakan pendidikan nilai, karena fiqih seperangkat aturan, norma dan nilai yang harus diterapkan dalam 
kehidupan manusia. Oleh karena itu, pembelajaran fiqih mempertimbangkan prinsip-prinsip dalam pendidikan nilai. Pendidikan nilai adalah penanaman dan pengembangan nilainilai dalam diri seseorang. Nilai berkaitan dengan standar baik buruk, benar salah, sehingga dengan mempelajarinya seseorang dapat menentukan pilihan dalam hidupnya, terkait dengan pilihannya benar atau salah, baik atau buruk. Sesunguhnya pendidikan nilai tidak harus menjadi mata pelajaran khusus yang berdiri sendidri, tetapi ia merupakan satu kesatuan yang melekat dalam seluruh aspek kehidupan.

Ada beberapa prinsip dalam pendidikan nilai, sebagaimana disebut dalam majalah CAMBUK (Caraka Masalah Budaya dan Konsistentisasi), yaitu: ${ }^{25}$ Pertama, nilai harus dipilih secara bebas. Kedua, nilai harus dipilih dari berbagai alternatif. Ketiga, nilai harus dipilih setelah mengadakan pertimbangan mengenai akibat-akibat pilihannya. Keempat, orang harus merasa bahagia dan gembira atas pilihannya. Kelima, orang yang memilih nilai tertentu harus berani menegaskan pilihannya didepan umum. Keenam, orang harus mau berbuat sesuatu untuk pilihannya tersebut. Ketujuh, perbuatan untuk nilainya tersebut harus di ulang-ulang sehingga terbentuk satu pola.

Berdasarkan prinsip-prinsip di atas, pendidikan nilai, termasuk di dalamnya pendidikan agama harus dilakukan dengan sepenuhnya melibatkan kesadaran dan pengamalan peserta didik. Peserta didik perlu dilibatkan secara aktif dalam menetukan tema yang akan dipelajari, sadar betul akan pilihannya dan bimbingan untuk mengalami secara langsung apa yang dipelajarinya.

25 Majalah CAMBUK, t.t, hlm. 5. 
Selain prinsip-prinsip di atas, pembelajaran nilai juga harus mempertimbangkan tingkat perkembangan peserta didik. Ada beberapa teori perkembangan yang dapat menjelaskan perkembangan peserta didik, diantaranya teori perkembangan kognitif yang dikembangkan oleh Jean Piaget. Piaget membagi perkembangan kognitif manusia menjadi 4 (empat) tahap. ${ }^{26}$

a. Tahap Sensorimotor, yang berlansung dari kelahiran hingga dua tahun. Pada tahap ini, bayi membangun suatu pemahaman tentang dunia dengan mengkoordinasikan pengalaman-pengalaman sensoris (seperti melihat dan mendengar) dengan tindakan-tindakan motorik fisik.

b. Tahap Praoperasional, yang berlangsung kira-kira 2-7 tahun. Pada tahap ini, anak-anak mulai melukiskan dunia dengan kata-kata dan gambar-gambar. Pemikiran simbolis melampaui hubungan sederhana antara informasi sensorik dan tindakan fisik. Akan tetapi walau anak-anak pra sekolah dapat secara simbolis melukiskan dunia, mereka belum mampu melakukan apa yang Piaget sebut "operasi " yaitu tindakan mental yang memungkinkan anak-anak melakukan secara mental apa yang dilakukan secara fisik.

c. Tahap Operasional Konkret yang berlangsung kira-kira usia 7-11 tahun. Pada tahap ini, anak-anak dapat melakukan operasi dan penalaran logis menggantikan intuitif sejauh pemikiran dapat diterapkan ke dalam contoh-contoh yang spesifik atau konkret.

26 John W. Santrock, Life Span Development: Perkembangan Masa Hidup, (Jakarta: Erlangga, 2002), hlm. 44-45. 
d. Tahap Operasianal Formal, berlangsung antara 11-15 tahun dan lebih dari itu. Pada tahap ini individu melampaui dunia nyata, pengalaman-pengalaman konkrit dan berpikir secara Abstrak dan lebih logis. Sebagai bagian dari pemikiran yang Abstrak, anak-anak remaja mengambarkan keadaan yang ideal. Mereka dapat membayangkan seperti apakah orang tua yang ideal. Mereka mulai mempersiapkan kemungkinan-kemungkinan bagi masa depan dan terkagum-kagum terhadap apa yang mereka lakukan dalam memecahkan masalah, pemikir operasional ini lebih sistematis, mengembangkan hipotesis tentang mengapa sesuatu terjadi seperti itu, kemudian menguji hipotesis dengan cara deduktif. Pembelajaran nilai bagi siswa perlu mempertimbangkan tingkat perkembangan kognitif ini, dimana pada masa ini peserta didik sudah berpikir hipotesis, analitis, mencari hubungan sebab akibat dari suatu fenomena, sehingga pembelajaran yang menekankan pada aspek hafalan semata sebaiknya dikurangi.

\section{METODE PENELITIAN}

\section{A. Jenis dan Desain Penelitian}

Jenis penelitian ini adalah penelitian lapangan (field research), yang menjadikan data lapangan sebagai data primer. Penelitian lapangan menurut Nawawi adalah suatu penelitian yang dilaksanakan secara intensif dan terperinci 
terhadap suatu objek yang diinginkan dengan mempelajarinya berbagai data penguatan atau pendukung suatu kasus. ${ }^{27}$

Sumber data dibagi menjadi dua, yaitu data primer dan sumber data sekunder. Data primer terdiri dari jawaban para responden terhadap angket atau kuesioner penelitian yang diberikan kepada guru, serta dokumen pembelajaran yang berupa silabus dan Satuan Acara Pembelajaran (SAP) guru. Sedangkan data sekunder adalah buku-buku yang berkaitan dengan mata pelajaran yang diteliti. Sedangkan desain penelitian ini adalah desain kualitatif data akan dikumpul dan dianalisis dengan metode kualitatif.

\section{B. Subjek dan Lokasi Penelitian}

Subjek dalam penelitian ini adalah guru fiqih MTs Muhammadiyah Gedongtengen kota Kota Yogyakarta. Responden adalah siswa kelas VII MTs Muhammadiyah yang mengikuti pembelajaran fiqih. Sebanyak 2 kelas, kelas VII A berjumla 14 dan kelas VII B berjumlah 15 siswa jadi dua kelas berjumlah 29 siswa. Lokaasi penelitian ini adalah di MTs Muhammadiyah Gedongtengen Kota Yogyakarta.

\section{Teknik Pengumpulan Data}

1. Angket

Teknik pengumpulan data dengan angket merupakan metode yang dimaksudkan untuk menambah kelengkapan data dari apa yang di dapat dari responden, maka angkat di pandang sebagai interview tertulis. ${ }^{28}$ Angket dalam penelitian ini dimaksudkan untuk mengungkap hasil dari penggunaan Strategi Active Learning dalam pembelajaran fiqih di MTs

27 Rifa'i Abubakar, dkk, Motivasi dan Ekspektasi Mahasiswa Mengikuti Pembelajaran Mata Kuliah PAI, (Kota Yogyakarta: STAIMS, 2010), hlm. 55.

28 Op.Cit hlm.58. 
Gedongtengen Kota Yogyakarta. Angket yang dibagikan kepada responden kelas A dan responden kelas B yang berjumlah keseluruhan 29 orang, pertimbangan di ambil semua karena kurang dari 100 orang, merujuk kepada teori Suharsimi Arikunto apa bila kurang dari 100 orang, maka di ambil semua.

2. Wawancara

Teknik wawancara dilakukan untuk mendalami pertanyaan-pertanyaan yang belum dapat diungkap dengan angket yang telah dibagikan. Wawancara dilakukan terhadap guru fiqih yang mengajar di kelas VII .Untuk mendapatkan data tentang bagaimana hasil pelajaran fiqih dengan menggunakan Strategi Active Learning .

\section{Instrumen Penelitian}

Sesuai dengan teknik pengumpulan data dalam penelitian ini ada dua cara, yakni angket dan wawancara. Angket disusun untuk mengetahui hasil tentang penggunaan Strategi Active Learning pada mata pelajaran fiqih. Sedangkan wawancara dilakukan kepada guru fiqih, untuk mengungkapkan apa harapan guru terhadap materi, metode, strategi, sumbel belajar, media, tenaga pengajar, dan kebijakan lain dalam pembelajaran fiqih.

\section{HASIL PENELITIAN DAN PEMBAHASAN}

\section{A. Gambaran Umum Lokasi Penelitian}

\section{Sejarah Berdirinya}

Madrasah Tsanawiyah Muhammadiyah Gedongtengen Kota Yogyakarta terletak dekat pusat perbelanjaan. Madrasah ini berdiri pada tanggal 21 April tahun 1978. Sebelum Madrasah Tsanawiyah ini dibangun yang sekarang 
ini terletak di Jalan Dagen Nomor 82, proses belajar mengajar dilakukan di salah satu toko Muhammadiyah di wilayah cabang Gedongtengen di rumah Abdul Syukur di Jalan Dagen Kota Yogyakarta. ${ }^{29}$

Alhamdulillah atas kepiawaian Muhammadiyah cabang Gedongtengen, membuat Madrasah Tsanawiyah ini menjadi berkembang, mengikuti perkembangan zaman, sehingga sesuai dengan Visi dan Misi Madrasah Tsanawiyah Muhammadiyah Kota Yogyakarta.

\section{Tujuan didirikannya Madrasah Tsanawiyah}

\section{Muhammadiyah Gedongtengen Kota Kota Yogyakarta}

a. Tercapainya Profesionalisme guru

b. Tercapainya profosionalitas karyawan

c. Tercapainya kedisiplinan dan keterlibatan di lingkungan madrasah

d. Terwujudnya lulusan yang berkualitas dan berakhlak mulia

e. Terwujudnya siswa yang kreatif, inovatif dan mandiri

\section{Visi dan Misi}

Visi dan misi Madrasah Tsanawiyah Muhammadiyah Gedongtengen Kota Yogyakarta adalah:

a. Visi Madrasah Tsanawiyah (MTs) Muhammadiyah Gedongtengen "Menjadi Lembaga Pendidikan yang Unggul Islam dan Mandiri."

b. Misi Madrasah Tsanawiyah (MTs) Muhammadiyah Gedongtengen adalah: Pertama, meningkatkan kinerja guru dan karyawan. Kedua, meningkatkan motivasi belajar siswa. Ketiga, melatih dan mengikut sertakan siswa dalam berbagai perlombaan. Keempat, menanamkan $5 \mathrm{~S}$ di

29 Hasil dokumentasi dan wawancara dengan Ibu Wakil Kepala Sekolah bagian Kurikulum tanggal 3 Februari 2018 
lingkungan Madrasah. Kelima, membuat Statistik perkembangan nilai UN. Keenam, mengupayakan warga Madrasah menjalankan Syariat Islam. Ketujuh, membekali siswa dengan Keterampilan life skill.

\section{Struktur Organisasi Madrasah Tsanawiyah Muhammadiyah}

\section{Gedongtengen Kota Yogyakarta}

Struktur disetiap bagian diwajibkan membuat rencana secara rinci yang akan dilaksanakan selama satu priode, dalam hal ini dimaksudkan agar setiap rencana yang dilaksanakan tidak saling berbenturan antar satu dengan yang lainnya tetapi harus menjadi satu kesatuan yang harmonis yang sesuai dengan program sekolah pada umumnya. Berdasarkan fungsi rencana kerja yang sudah disusun. 30

\section{B. Hasil Penelitian}

\section{Tujuan Penerapan Strategi Active Learning}

Tujuan penerapan strategi active learning dalam pembelajarn fiqih adalah sebagai berikut: Pertama, meningkatkan wawasan dan pemahaman tentang materi pelajaran. Kedua, meningkatkan partisipasi aktif peserta didik. Ketiga, menumbuhkan motivasi dan minat peserta didik dalam belajar. Keempat, melatih daya kritis peserta didik melalui diskusi maupun pada saat kegiatan pembelajaran. Kelima, meningkatkan kemampuan dalam mengkomunikasikan ide, fikiran dan gagasan.

30 Hasil observasi dan wawancara dengan Bapak $H$. Sudarwan,S.Pd.I,M.Pd.I, Guru Mata Pelajaran Fiqh, tanggal 3 Februari 2018 


\section{Manfaat yang diperoleh dari Penerapan Strategi Active Learning}

Manfaat yang diperoleh dari penerapan strategi active learning dalam pembelajaran fiqih siswa kelas VII pada semester ganjil di MTs Muhammadiyah Gedongtengen Kota Yogyakarta adalah sebagai berikut:

a. Interaksi yang timbul selama proses pembelajaran akan menimbulkan positive interdefendence dimana konsolidasi pengetahuan yang dipelajari hanya dapat diperoleh secara bersama-sama melalui eksplorasi aktif dalam belajar.

b. Setiap individu harus terlibat aktif dalam proses pembelajaran dan pengajar harus mendapatkan penilaian untuk setiap peserta didik, sehingga terdapat individual accountability.

c. Proses pembelajaran aktif ini agar berjalan dengan efektif diperlukan tingkat kerjasama yang tinggi sehingga dapat memupuk sosial skill.

d. Mempermudah tersampainya materi.

e. Memberikan nuansa lain dalam tiap aktivitas.

f. Memudahkan dalam melakukan assesment proses.

3. Hal-hal yang dilakukan Guru agar Anak Didik Merasa Nyaman

Hal-hal yang dilakukan guru agar anak didik selalu merasa nyaman dan senang ketika proses belajar mengajar adalah sebagai berikut: 31

a. Menciptakan situasi belajar yang dialogis dan komunikatif dengan subjek didik. Subjek didik harus

31 Hasil observasi dan wawancara dengan Bapak H. Sudarwan, SPd.I,MPd.I, Guru Mata Pelajaran Fiqh, tanggal 3 Februari 2018 
ditempatkan sebagai teman belajar yang dianggap sudah memiliki " pengertian awal"

b. Menciptakan situasi yang menyenangkan yang dapat merangsang motivasi subjek didik untuk belajar

c. Mendesain materi ajar dengan membuat rencana pelaksanaan pembelajaran (RPP) agar memiliki acuan mengajar yang jelas

d. Membuat alat bantu pembelajaran terkait materi, agar materi mudah dipahami subjek didik, serta dituntut untuk secara kreatif dalam menyampaikan materi seperti membuat alat bantu mengajar. Alat bantu pembelajaran sangat penting karena mampu mengatasi keterbatasan artikulasi lisan, bahkan dalam filsafat pendidikan terdapat sebuah prinsip yang mengatakan bahwa metode pembelajaran itu lebih penting dari materi.

\section{Hal-hal yang dilakukan Guru dalam Memberi Motivasi kepada Anak Didik}

Hal-hal yang dapat dilakukan guru dalam memberikan motivasi agar anak didik ikut berperan aktif dalam proses pembelajaran ketika mengajar adalah sebagai berikut:

a. Berusaha membangkitkan dorongan kepada siswa untuk belajar

b. Berusaha menjelaskan kepada siswa secara konkrit apa yang dapat dilakukan pada akhir pengajaran.

c. Berusaha memberikan hadiah terhadap prestasi yang dicapai sehingga dapat merangsang tercapainya prestasi yang lebih baik di kemudian hari

d. Membentuk kebiasaan belajar yang baik.

e. Membuat dinamika group agar siswa yang statis menjadi dinamis 
Hasil penerapan Strategi active learning dalam pembelajaran fiqih siswa kelas VII pada semester ganjil di Madrasah Tsanawiyah Muhammadiyah Gedongtengen Kota Yogyakarta adalah:

Tabel 1

Motivasi Untuk Lebih Giat Dalam Mempelajari Fiqh

\begin{tabular}{|c|l|c|c|}
\hline Item & Alternatif jawaban & Frekuensi & Persentase \\
\hline \multirow{3}{*}{1} & a. Selalu & 20 & $70 \%$ \\
& b. Kadang-kadang & 6 & $20 \%$ \\
& c. Tidak pernah & 3 & $10 \%$ \\
\hline \multicolumn{2}{|c|}{ Jumlah } & 29 & $100 \%$ \\
\hline
\end{tabular}

Sumber: dari hasil angket siswa di MTs Muhammadiyah Gedongtengen Kota Yogyakarta tanggal 10 Februari 2018

Berdasarkan dari hasil angket yang sudah peneliti bagikan maka hasilnya adalah, Guru fiqih telah berhasil menerapkan strategi active learning. Hal tersebut dapat dibuktikan dengan 20 jawaban responden yang menyatakan selalu termotivasi untuk lebih giat belajar mata pelajaran fiqih, sedangkan 6 responden yang menyatakan kadangkadang dan 3 responden yang menjawab tidak termotivasi.

\section{Tabel 2}

Menumbuhkan Kepercayaan Diri Untuk Menguasai Fiqh

\begin{tabular}{|c|l|c|c|}
\hline Item & Alternatif jawaban & Frekuensi & Persentase \\
\hline \multirow{3}{*}{2} & a. Selalu & 23 & $80 \%$ \\
& b. Kadang-kadang & 4 & $14 \%$ \\
& c. Tidak pernah & 2 & $6 \%$ \\
\hline \multicolumn{2}{|c|}{ Jumlah } & 29 & $100 \%$ \\
\hline
\end{tabular}

Sumber : dari hasil angket siswa di MTs Muhammadiyah Gedongtengen Kota Yogyakarta tanggal 10 Februari 2018

Berdasarkan tabel di atas Guru fiqih berhasil menerapkan strategi active learning hal tersebut dapat 
dibuktikan dengan 23 responden yang menyatakan selalu menumbuh kepercayaan diri untuk menguasai fiqih, sedangkan yang menyatakan kadang-kadang 4 responden, dan yang tidak pernah 2 responden.

Tabel 3

Merasa Penting Mempelajari Fiqh

\begin{tabular}{|c|l|c|c|}
\hline Item & Alternatif jawaban & Frekuensi & Persentase \\
\hline \multirow{3}{*}{3} & a. Selalu & 23 & $80 \%$ \\
& b. Kadang-kadang & 6 & $20 \%$ \\
& c. Tidak pernah & 0 & $0 \%$ \\
\hline \multicolumn{2}{|c|}{ Jumlah } & 29 & $100 \%$ \\
\hline
\end{tabular}

Sumber : dari hasil angket siswa di MTs Muhammadiyah Gedongtengen Kota Yogyakarta tanggal 10 Februari 2018

Berdasarkan tabel di atas guru fiqih telah berhasil menerapkan strategi active learning, hal itu dapat dibuktikan dengan 23 responden mengatakan penting mempelajari fiqih , dan yang menjawab kadang-kadang 6 responden, sedangkan yang menjarab tidak penting 0 responden.

\section{Kenyamanan Kondisi Kelas ketika Proses Belajar Fiqh Berlangsung}

\begin{tabular}{|c|c|c|c|}
\hline Item & Alternatif jawaban & Frekuensi & Persentase \\
\hline 4 & $\begin{array}{l}\text { a. Selalu } \\
\text { b. Kadang-kadang } \\
\text { c. Tidak pernah }\end{array}$ & $\begin{array}{c}17 \\
8 \\
4\end{array}$ & $\begin{array}{l}59 \% \\
28 \% \\
13 \%\end{array}$ \\
\hline & Jumlah & 29 & $100 \%$ \\
\hline
\end{tabular}

Sumber : dari hasil angket siswa di MTs Muhammadiyah Gedongtengen Kota Yogyakarta tanggal 10 Februari 2018

Berdasarkan tabel diatas guru fiqih telah berhasil menerapkan strategi active learning, hal tersebut dapat dibuktikan dengan 17 responden yang menyatakan nyaman 
dengan kondisi kelas ketika proses belajar fiqih yang menyatakan kadang- kadang 8 responden, yang mengatakan tidak nyaman 4 responden.

Tabel 5

Kemampuan Membaca dan Menulis Tulisan Arab dengan Benar

\begin{tabular}{|c|l|c|c|}
\hline Item & Alternatif jawaban & Frekuensi & Persentase \\
\hline \multirow{3}{*}{5} & a. Selalu & 21 & $72 \%$ \\
& b. Kadang-kadang & 7 & $24 \%$ \\
& c. Tidak pernah & 1 & $4 \%$ \\
\hline \multicolumn{2}{|c|}{ Jumlah } & 29 & $100 \%$ \\
\hline
\end{tabular}

Sumber : dari hasil angket siswa di MTs Muhammadiyah

Gedongtengen Kota Yogyakarta tanggal 10 Februari 2018

Berdasarkan tabel di atas guru fiqih telah berhasil menerapkan strategi active learning, hal tersebut dapat dibuktikan denga 21 responden menyatakan bisa membaca dan menulis tulisan arab dengan benar, sedangkan yang kadang-kadang 7 responden yang tidak bisa 1 responden.

Tabel 6

Melafalkan Mufradat Baru dengan Makhraj yang Baik dan Benar

\begin{tabular}{|c|l|c|c|}
\hline Item & Alternatif jawaban & Frekuensi & Persentase \\
\hline \multirow{3}{*}{6} & a. Selalu & 20 & $68 \%$ \\
& b. Kadang-kadang & 7 & $24 \%$ \\
& c. Tidak pernah & 2 & $8 \%$ \\
\hline \multicolumn{2}{|c|}{ Jumlah } & 29 & $100 \%$ \\
\hline
\end{tabular}

Sumber : dari hasil angket siswa di MTs Muhammadiyah

Gedongtengen Kota Yogyakarta tanggal 10 Februari 2018

Berdasarkan tabel diatas guru fiqih telah berhasil menerapkan Strategi active learning, itu terbukti dengan 20 responden menjawab bisa melafalkan mufradat baru dengan 
makhraj yang benar, yang kadang-kadang 7 responden, yang tidak bisa menjawab 2 responden.

\section{Tabel 7}

\section{Melengkapi Qira'ah/Bacaan dengan Harakat yang Benar}

\begin{tabular}{|c|l|c|c|}
\hline Item & Alternatif jawaban & Frekuensi & Persentase \\
\hline \multirow{4}{*}{7} & a. Selalu & 23 & $80 \%$ \\
& b. Kadang-kadang & 5 & $17 \%$ \\
& c. Tidak pernah & 1 & $3 \%$ \\
\hline \multicolumn{2}{|c|}{ Jumlah } & 29 & $100 \%$ \\
\hline
\end{tabular}

Sumber : dari hasil angket siswa di MTs Muhammadiyah

Gedongtengen Kota Yogyakarta tanggal 10 Februari 2018

Berdasarkan tabel di atas guru fiqih telah berhasil menerapkan strategi active learning, itu terbukti dengan 23 responden menjawab bisa dan yang menjawab kadang-kadang 5 responden yang menjawab tidak bisa 1 responden.

\section{Tabel 8}

\section{Mempraktekkan Materi Fiqh}

\begin{tabular}{|c|l|c|c|}
\hline Item & Alternatif jawaban & Frekuensi & Persentase \\
\hline \multirow{3}{*}{8} & a. Selalu & 21 & $72 \%$ \\
& b. Kadang-kadang & 8 & $28 \%$ \\
& c. Tidak pernah & 0 & $0 \%$ \\
\hline \multicolumn{2}{|c|}{ Jumlah } & 29 & $100 \%$ \\
\hline
\end{tabular}

Sumber : dari hasil angket siswa di MTs Muhammadiyah

Gedongtengen Kota Yogyakarta tanggal 10 Februari 2018

Berdasarkan tabel di atas guru fiqih telah berhasil menerapkan strategi active learning, itu terbukti dengan 21 responden menjawab selalu mempraktikkannya dalam kehidupan sehari-hari dan yang kadang-kadang 8 responden, yang tidak pernah 0 responden. 


\section{Tabel 9}

Mendiskusikan Materi Fiqh yang Belum dipahami

\begin{tabular}{|c|l|c|c|}
\hline Item & Alternatif jawaban & Frekuensi & Persentase \\
\hline \multirow{3}{*}{9} & a. Selalu & 15 & $52 \%$ \\
& b. Kadang-kadang & 9 & $31 \%$ \\
& c. Tidak pernah & 5 & $17 \%$ \\
\hline \multicolumn{2}{|c|}{ Jumlah } & 29 & $100 \%$ \\
\hline
\end{tabular}

Sumber : dari hasil angket siswa di MTs Muhammadiyah

Gedongtengen Kota Yogyakarta tanggal 10 Februari 2018

Berdasarkan tabel di atas guru fiqih telah berhasil menerapkan strategi active learning, ini terbukti dengan 15 responden menjawab selalu mendiskusikan materi pelajaran Fiqih yang belum dipahami, yang kadang-kadang mendiskusikannya sebanyak 9 responden sedangkan yang menjawab tidak pernah 5 responden.

Tabel 10

Merasa Senang dengan Penerapan Metode Belajar Aktif dalam Pembelajaran Fiqh

\begin{tabular}{|c|l|c|c|}
\hline Item & Alternatif jawaban & Frekuensi & Persentase \\
\hline \multirow{3}{*}{10} & a. Selalu & 20 & $68 \%$ \\
& b. Kadang-kadang & 8 & $28 \%$ \\
& c. Tidak pernah & 1 & $4 \%$ \\
\hline \multicolumn{2}{|c|}{ Jumlah } & 29 & $100 \%$ \\
\hline
\end{tabular}

Sumber : dari hasil angket siswa di MTs Muhammadiyah

Gedongtengen Kota Yogyakarta tanggal 10 Februari 2018

Berdasarkan tabel di atas guru fiqih telah berhasil menerapkan strategi active learning, ini terbukti dengan 20 responden menjawab senang dengan penerapan active learning pada pembelajaran fiqih, yang menjawab kadangkadang sebanyak 8 responden yang tidan senang menjawab 1 responden. 


\section{PENUTUP}

\section{A. Kesimpulan}

1. Penerapan strategi active learning dalam pembelajarn fiqih siswa kelas VII pada semester ganjil di Madrasah Tsanawiyah Muhammadiyah Gedongtengen Kota Yogyakarta meliputi, tujuan, manfaat, hal-hal yang dilakukan guru supaya anak didik selalu merasa nyaman dan senang ketika proses belajar mengajar. Hal lain yang dilakukan guru fiqih adalah selalu memberikan motivasi agar anak didik ikut berperan aktif dalam proses pembelajaran fiqih.

2. Hasil dari penerapan Strategi active learning dalam pembelajaran fiqih belum $100 \%$ berhasil, hal tersebut ditunjukkan dengan hasil angket siswa dan hasil observasi di sekolah.

\section{B. Saran}

Berdasarkan kesimpulan di atas, beberapa saran dapat diberikan terkait dengan penelitian yang sudah dilakukan adalah:

1. Diharapkan kepada guru fiqih khususnya dan guru pada umumnya harus mampu menciptakan inovasi-inovasi baru tentang metode belajar yang efektif dan efisien, dengan kata lain selalu meningkatkan profesionalitas sebagai pendidik.

2. Pihak sekolah hendaknya lebih menjalin hubungan atau kerjasama dengan orang tua untuk bersama-sama memotivasi putra putrinya agar selalu aktif dalam kegiatan belajar disekolah maupun dirumah 
Sutinah dan Nahrasyiah Kamala : Implementasi Strategi Active Learning

3. Kepada para siswa hendaknya menyadari pentingnya belajar fiqih, karena fiqih berkaitan dengan kehidupan sehari-hari, terutama dalam pengamalan shalat lima waktu. 


\section{DAFTAR PUSTAKA}

Ahmad Rohani, Abu Ahmadi, 1995, Pengelolaan Pengajaran, Jakarta: PT. Rineka Cipta.

Amir Syaifuddin, 2003, Garis-garis Besar Fiqih, Bogor: Kencana.

Cece Wijaya, Djadjar Djadjur, A. Tabrani Rosyan, 1992, Upaya Pembaharuan Dalam Pendidikan dan Pengajaran, Bandung: Remaja Rosdakarya.

Dakir, 1991, Psikologi. Kota Yogyakarta: Pustaka Pelajar.

Dimyati, Mudjiono, 2006, Belajar dan Pembelajaran, Jakarta: PT. Rineka Cipta.

Firdaus, dkk, 2010, Model Silabus dan Rencana Pelaksanaan Pembelajaran (RPP) Mata Pelajaran Fikih Madrasah Tsanawiyah, Jakarta: Direktorat Pendidikan Madrasah.

Hisyam Zaini, Barmawi Munthe, Sekar Ayu Aryani, 2008, Strategi Pembelajaran Aktif. Kota Yogyakarta: Pustaka Insan Madani.

Mei Selberman, 1996, Active Learning 101 Pembelajaran Aktif, Kota Yogyakarta: Pustaka Insani Madani.

Santrock W. John,1995, Life Span Development: Perkembangan Masa Hidup, Jilid I, Jakarta: Erlangga.

Syaiful Bahri Djamarah, Azwa Zein, 2002, Strategi Belajar Mengajar, Jakarta: Rineka Cipta.

Umi Machmudah, Abdul Wahab Rosyidi, 2008, Active Learning dalam Pembelajaran Bahasa Arab, Malang: UIN Malang Press.

Rifa'i Abubakar, dkk,2010, Motivasi dan Ekspektasi Mahasiswa Mengikuti Pembelajaran Mata Kuliah Pendidikan Agama Islam di PT, Kota Yogyakarta: SEKOLAH TINGGI AGAMA ISLAMMS.

Sriyono, dkk, 1992, Teknik Belajar Dalam CBSA, Jakarta: PT. Rineka Cipta. 
Sumadi Suryabrata, 1998, Psikologi Pendidikan, Jakarta: Rajawali Press.

Sardiman, 2007, Interaksi dan Motivasi Belajar Mengajar, Jakarta: PT: Raja Grafindo Persada.

Tata Yusuf, Syaiful Anwar, 1995, Metodologi Pengajaran Agama dan Bahasa Arab, Jakarta: Raja Grafindo Persada.

Wasty Soemanto, 1990, Psikologi Pendidikan, Jakarta: Rineka Cipta.

Zainal Aqib, 2010, Profesionalisme Guru Dalam Pembelajaran, Surabaya: Insan Cendekia. 
Sutinah dan Nahrasyiah Kamala : Implementasi Strategi Active Learning

38 Jurnal Komunikasi dan Pendidikan Islam, Volume 7, Nomor 1, Juni 2018 